
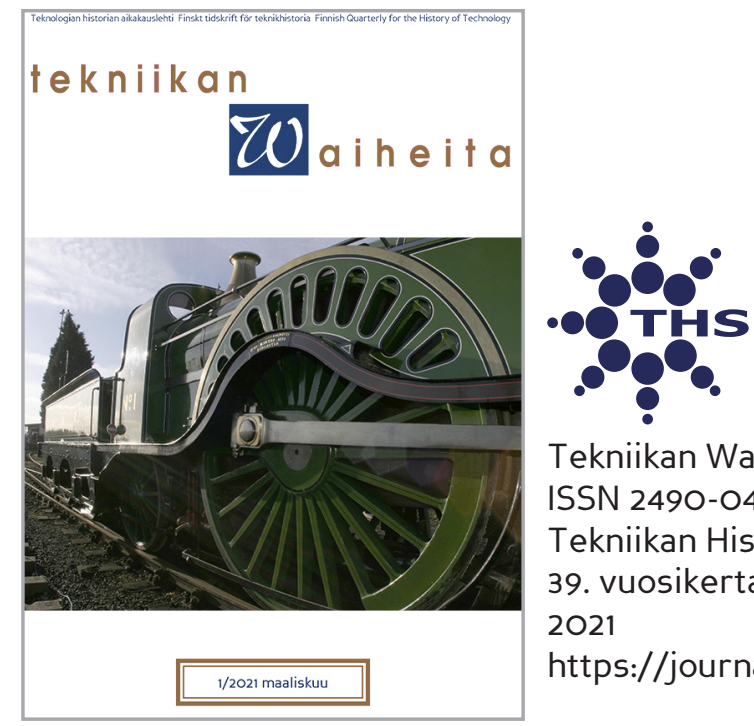

Tekniikan Waiheita

ISSN 2490-0443

Tekniikan Historian Seura ry.

39. vuosikerta: 1

2021

https://journal.fi/tekniikanwaiheita

\title{
Suomen merimuseon museolaivakuulumisia
}

Johanna Aartomaa ja Juha Puustinen

To cite this article: Johanna Aartomaa ja Juha Puustinen, "Suomen merimuseon museolaivakuulumisia" Tekniikan Waiheita 39, no. 1 (2021): 74-78. https://doi.org/10.33355/ tw.103199

To link to this article: https://doi.org/10.33355/tw.103199 


\title{
Suomen merimuseon museolaivakuulumisia
}

\author{
Johanna Aartomaa ja Juha Puustinen ${ }^{1}$
}

Katsaus käsittelee Suomen merimuseon suurimpien museoalusten ylläpitoa. Höyryjäänmurtaja Tarmo telakoitiin viimeksi vuosina 2016-2017, ja majakkalaiva Kemin tekointi alkoi talvella 2020-2021. Molemmat alukset ovat kansallisesti merkittäviä museolaivoja, jotka on päätetty museoida heti käyttövuosiensa jälkeen. Katsaus avaa suurten museolaivojen telakointiin liittyvää tutkimusta, työtehtäviä ja yllätyksiä.

Englannissa (Newcastle upon Tyne) rakennettu Tarmo oli valmistuessaan vuonna 1907 Suomen suuriruhtinaskunnan kolmas jäänmurtaja. Tarmo oli käytössä vuoteen 1970 asti. Kunnostamisen jälkeen alus sijoitettiin vuonna 1992 Kotkaan yleisön nähtäville.

Majakkalaiva Kemi on rakennettu Rosenlew Oy:n Porin konepajalla. Alus oli yksi Suomen viidestätoista majakkalaivasta ja oli käytössä vuosina 1901-1974. Vuodesta 1960 lähtien Kemi oli Suomen ainoa käytössä ollut majakkalaiva, sillä kiinteiden majakoiden myötä majakkalaivat jäivät tarpeettomiksi.

Kemi avattiin yleisölle ensimmäisen kerran vuonna 1989 Helsingissä. Nyt valmistellaan uutta avaamista pitkän tauon jälkeen.

\section{Jäänmurtaja Tarmon telakointi}

Jäänmurtaja Tarmon viimeisin telakointi tapahtui vuonna 2016-2017. Telakalla kunnostettiin neljä painolastitankkia. Aluksen runko ja kansirakenteet tarkastettiin ja maalattiin, pelastusvenekansi uusittiin, pelastusveneet korjattiin sekä lisäksi tehtiin pienempiä korjauksia.

Tarmon sisätilat ovat 1950-1952 tehdyn viimeisen merkittävän uudistuksen mukaisessa asussa eikä niihin kajottu viimeisimmässä telakoinnissa. Aluksen keskeiset tilat kuitenkin dokumentoitiin Metropolia-ammattikorkeakoulun opiskelijatyönä. Opiskelijat toteuttivat 360-kuvista virtuaalikierroksen, jonka käsikirjoituksen tekivät Suomen merimuseon asiantuntijat. Virtuaalikierros on julkaistu Suomen kansallismuseon sivuilla. ${ }^{2}$

Samalla luetteloitiin ja valokuvattiin jäänmurtaja Tarmon mittava esineistö sekä konservoitiin alukseen liittyviä paperi- ja tekstiiliaineistoja. Aluksen esine- ja arkistokokoelmaan voi tutustua Finna.fi -hakupalvelussa. ${ }^{3}$

\footnotetext{
${ }^{1}$ Kirjoittajat työskentelevät Suomen kansallismuseon osana toimivassa Suomen merimuseossa. Aartomaa museolehtorina ja Puustinen vene- ja laivamestarina.

${ }^{2}$ Museojäänmurtaja Tarmon virtuaalikierros tarmo.kansallismuseo.fi/.

${ }^{3}$ Finna.fi, hakutulos www.finna.fi/Search/Results?limit=0\&lookfor =tarmo\&type =AllFields\&filter\%5B\%5D $=\sim$ buil ding\%3A\%220\%2FSuomen+merimuseo\%2F\%22.
} 


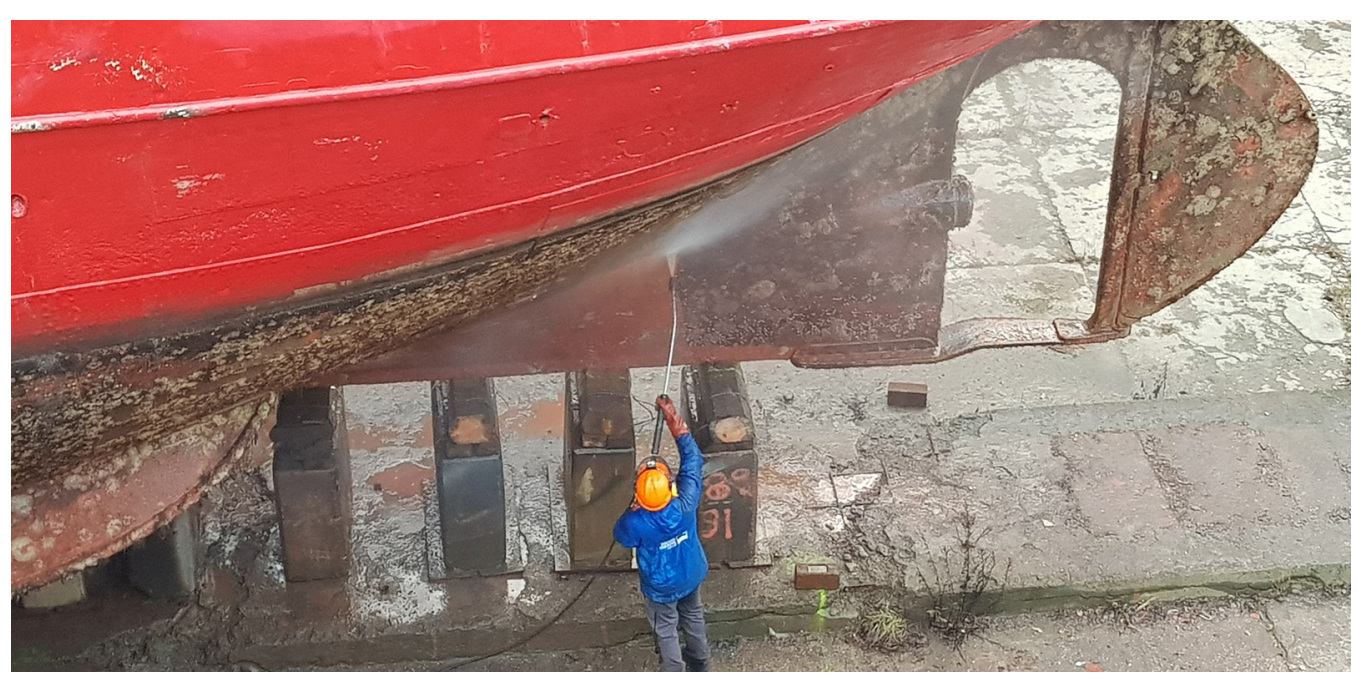

Kuva 1. Majakkalaiva Kemin pohjaa pestään telakalla. Päivi Lepistö. Suomen merimuseo.

\section{Majakkalaiva Kemin laaja restaurointi}

Majakkalaiva Kemin restaurointihanke on laivan kokoon nähden pienempi kuin Tarmon telakointi, mutta kattavuudeltaan laajempi. Rungon kunnostuksen lisäksi restauroidaan sisätiloja ja tehdään kokonaan uusi näyttely. Tarmoon verrattuna Kemin restaurointi on suunnitteluineen moninkertainen.

Kemin nykyinen restaurointi on alkanut jo 2007, jolloin alus hinattiin Kotkaan. Tuolloin alkaneiden korjausten taustalla oli suurelta osin vuotava sääkansi, jonka takia hyttikannella on vaurioita.

Kotkassa laivaan rakennettiin uusi sääkansi männystä. Vuoteen 2003 asti avoinna olleesta aluksesta purettiin vanha näyttely ja korjattiin pääkannen puisia hyttirakenteita. 1980-luvulla hyttikannelle tehdyt tutkijoiden majoitustilat purettiin.

Myös majakkalaiva Kemin esinekokoelma kootaan eri säilytyspaikoista Kotkaan, luettelointitietoja tarkistetaan ja esineet kuvautetaan. Esinekokoelma avataan kokonaisuudessaan Finna.fi -palvelussa.

\section{Kemin telakointi}

Majakkalaiva Kemin edellisessä telakoinnissa vuosina 2005-2007 runkolevyjen paksuus mitattiin ja pohja pintakäsiteltiin. Nyt museossa nähtiin tärkeäksi saada runko kunnostettua. Rungossa on vain muutama laipio, jotka nekään eivät ole kaikki vesitiiviitä. Näin ollen lähes koko runko on käytännöllisesti katsoen yhtä tilaa, mikä on merkittävä riski mahdollisen vuodon sattuessa.

Tätä kirjoittaessa alus on telakoitu Suomenlinnan historialliselle kuivatelakalle, missä Suomen valtion jäänmurtajia telakoitiin ensimmäisen kerran vuonna 1918. Kemin ulko- 
pinta on pesty ja rungon kunnostuksen valmistelevia töitä on tehty. Pilssistä on piikattu pois 1980-luvulla lisätty betoni sekä ruoste ja vanha maali.

Aluksen rungon kuntokartoitusta on täydennetty. Kemin runkolevytys ja kylkien kaaret osoittautuivat melko hyväkuntoiseksi. Sen sijaan muutaman laipion alareuna sekä neljäkymmentä huonokuntoista kölitukkia joudutaan uusimaan.

Rungon korjaustyöt käynnistetään kilpailutuksen päätyttyä. Runko tullaan pintakäsittelemään ulko- ja sisäpuolelta ja aluksen puuosia tullaan kunnostamaan.

\section{Hyvät olosuhteet suojaavat alusta}

Telakoinnin jälkeen keskeistä on aluksen olosuhteiden hallinta, joka on Kemillä haastavaa. Aluksen LVI-suunnittelussa tilat on jaettu eri vyöhykkeisiin, joissa pyritään hyvään ilmanvaihtoon. Osassa pyritään tämän lisäksi pitämään lämpötila hieman ulkolämpötilaa korkeampana.

Aluksen säilymiseksi siihen suunnitellaan suojakatosta talvien ajaksi. Lisäksi sääkannen kansilaitteita suojataan erillisillä suojapeitteillä, kuten jäänmurtaja Tarmollakin on käytäntönä.

Alukseen laaditaan sähkösuunnitelma, jossa otetaan huomioon paitsi valaistus myös muu nykyaikaisen näyttelyn vaatima tekniikka, hälytysjärjestelmät sekä rungon korroosiota estävä katodinen suojaus.

\section{Tietoa työn tueksi}

Molempiin aluksiin liittyen saamme kiittää merenkulkuhallinnon pitkäaikaista virkamiestä, merikapteeni Seppo Laurellia hänen mittavasta työstään laivojen ja niiden historian parissa. Laurellin kirja Höyrymurtajien aike ${ }^{4}$ on jokaisen Tarmon parissa työskentelevän perusteos aluksen historian osalta. Samoin hänen kirjoittamansa Aalloilla keinuvat majakat ${ }^{5}$ kuluu nyt käsissämme.

Osana Kemin restaurointihanketta on tehty Majakkalaiva Kemi - historiaselvitys. ${ }^{6}$ Arkkitehtitoimisto Livadyn tekemä selvitys käsittelee laivan suunnittelua ja rakentamista, käyttöä sekä museoaikaa restaurointi- ja muutosvaiheineen. Vastaavaa selvitystä ei ole aiemmin tehty Suomessa ja se nostaa museolaivojen dokumentoinnin uudelle tasolle Suomen merimuseossa.

Historiaselvitys on tärkeä osa tutkimusaineistoa, jota hyödynnetään restaurointilinjauksissa ja -suunnittelussa. Aluksen ylläpidosta vastaavan näkökulmasta se on käsikirja, josta voi tarkistaa lukuisia yksityiskohtia. Selvitys tiivistää mm. tietoa eri aikakausien kerrostumista aluksella, auttaa laivan näyttelysuunnittelussa ja aikanaan aluksen esittelyssä yleisölle.

Laivojen ja merenkulun historiasta kiinnostuneille selvitys tarjoaa katsauksen aluksen historiaan ja työhön majakkalaivalla. Niin Helsingin, Rauman kuin Kemin edustallakin merenkulkua turvannut alus on ollut olennainen osa Suomen merellistä kulttuuriperintöä.

\footnotetext{
${ }^{4}$ Laurell 1992.

${ }^{5}$ Laurell 1988.

${ }^{6}$ Majakkalaiva Kemi - Historiaselvitys. 2020. www.museovirasto.fi/fi/palvelut-ja-ohjeet/julkaisut/selvityksia-ja-raportteja\#Kulttuuriperint\%C3\%B6.
} 


\section{Museolaiva on elämys}

Jäänmurtaja Tarmo edustaa talvimerenkulun merkitystä ympärivuotiselle kaupankäynnille, kun taas majakkalaiva Kemi avaa merenkulun turvallisuuden eteen tehtyä työtä. Kumpikin on ollut valmistuessaan uutta teknologiaa, jonka esittelyn laivat laitteineen mahdollistavat. Kummankin aluksen kone- ja kattilahuoneet ovat säilyneet hyvin.

Museon yleisösuhteen luomisessa keskeisintä on kuitenkin rakentaa siltoja historiasta ihmisten arkeen yleisemmällä tasolla. Aidot interiöörit ovatkin kokonaisvaltaisen kokemuksen paikkoja, joiden esiintuominen kiinnostavalla tavalla vaikuttaa myös restauroinnin painotuksiin ja näyttelysisältöön.

\section{Lähteet}

\section{Kirjallisuus}

Laurell, Seppo. 1992. Höyrymurtajien aika. Historiikki höyrykäyttöisten valtionjäänmurtajien aikakaudesta. Merenkulkuhallituksen julkaisu. Merenkulkuhallitus. Helsinki.

Laurell, Seppo. 1988. Aalloilla keinuvat majakat. Historiikki majakkalaivojen aikakaudesta ja museoalus Kemistä. Merenkulkuhallitus. Helsinki.

\section{Verkkosivut}

Finna. Hakutulos hakusana "Tarmo", organisaatio "Suomen merimuseo". Haettu 7.2.2021. https://www.finna.fi/Search/Results?limit=0\&lookfor=tarmo\&type=AllFields\&filter\%5B\%5D= building\%3A $\% 220 \% 2 \mathrm{FSuomen}+$ merimuseo\%2F\%22.

Majakkalaiva Kemi - Historiaselvitys. 2020. Toim. Arkkitehtitoimisto Livady - Pasi Kolhonen, Mia Puranen, Marko Huttunen, Pauliina Saarinen \&Tuomas Ranta-aho. Helsinki: Museovirasto. Haettu 9.2.2021. https://www.museovirasto.fi/fi/palvelut-ja-ohjeet/julkaisut/selvityksia-ja-raportteja\#Kulttuuriperint\%C3 \%B6.

Museojäänmurtaja Tarmon virtuaalikierros. Haettu 7.2.2021. https://tarmo.kansallismuseo.fi/. 